\title{
After Professor Jürgen Koebke
}

\author{
Tania Marur \\ Department of Anatomy, Cerrahpaşa Medical Faculty, Istanbul University, Istanbul, Turkey \\ Anatomy 2012-2013;6-7:5, @ 2012-2013 TSACA
}

When I was asked to write Prof. Jürgen Koebke's obituary, I decided to write my thoughts what he meant for me. His scientific accomplishment impressed me. He was a famous scientist and a brilliant person with great heart for those who shared the same passion to contribute to the scientific world.

I met with him during a congress held in 1997 by the Anatomy Department of Cerrahpaşa Faculty of Medicine. This meeting in Istanbul has become the beginning of a scientific bridge between Cologne Anatomical Institute and Cerrahpaşa Anatomy Department. The foundation of not only scientific collaboration but also a long-term friendship was established. I consider myself lucky to meet with Jürgen Koebke during the infancy period of my professional career. Being able to be enlightened by his ability balancing the triangle of knowledge, student and teacher played an essential role for the development of my professional identity (Figure 1).

His passion to learn and teach was admired and appreciated not only by his colleagues but also by his students, and he was considered as the connoisseur of anatomy society. One of his characteristics that influenced me most was that he shared what he had in his hands and mind with others generously, and made people happy. I am sure that he was happy as well. I cannot forget his happy face during the organizations held in common.

We were never surprised about him thanks to his disciplined and determined personality and his attitude defending equity. Yet, he prepared surprises for us for each workshop by his agile mind.

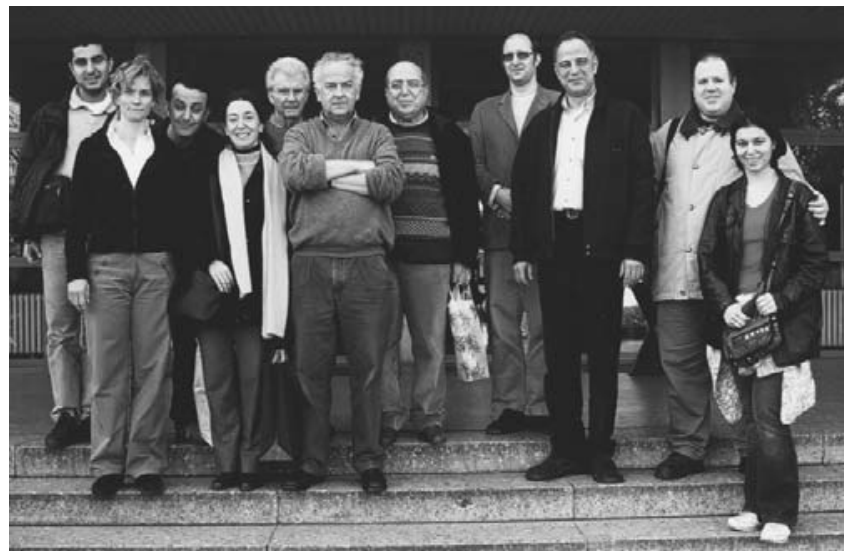

Figure 1. One of the best moments we gathered in the journey of our unforgettable friendship and collaboration. In front ot 'Zentrum Anatomie' of the University of Cologne, March 2004.

I commemorate him in every opportunity and remember the good old days. He visited many universities in Turkey. There were students and lecturers from various medicine faculties who contacted to work with him. Therefore, when we get together with my colleagues from either clinical or basic sciences, we remember Jürgen Koebke wistfully. He loved Turkey and was mentioning his love in each visit. He was the admirer of each part of Turkey. I believe that it will not be an exaggeration to describe him as a fan of Turkey. Yet, we are at a point where we fall short of words. Our only consolation is that his memoirs and love are remembered in many places.

Correspondence to: Professor Tania Marur, MD

Department of Anatomy, Cerrahpaşa Medical Faculty, Istanbul University, 34098 K.M.Paşa, Fatih, Istanbul, Turkey

Phone: +902124143000

e-mail: tania@mynet.com

Conflict of interest statement: No conflicts declared. 